\title{
A new genus and three new species of scorpions from Cretaceous Burmese amber (Scorpiones: Chaerilobuthidae: Palaeoeuscorpiidae)
}

\author{
Новый род и три новых вида скорпионов \\ из мелового бирманского янтаря (Scorpiones: \\ Chaerilobuthidae: Palaeoeuscorpiidae)
}

\author{
Wilson R. Lourenço \\ Вилсон Р. Аоуренсо
}

Muséum national d'Histoire naturelle, Département Systématique et Evolution, UMR7205, CP 053, 57 rue Cuvier, 75005 Paris, France. E-mail: arachne@mnhn.fr

KEY WORDS: scorpion, fossil, new genus, new species, Cretaceous, Burmese amber, Myanmar.

КЛЮЧЕВЫЕ СЛОВА: скорпион, ископаемый, новый род, новый вид, меловой период, бирманский янтарь, Мьянма.

ABSTRACT. A study of three new scorpion specimens from the Cretaceous amber of Myanmar (Burma) leads to descriptions of one new genus, Burmesescorpiops gen.n., with the sole, and type, species, $B$. groeh$n i$ sp.n., as well as of further two new species, Chaerilobuthus gigantosternum sp.n. and C. serratus sp.n., and to a confirmed validity of the subfamily Archaeoscorpiopinae Lourenço, 2015. At present, 18 scorpions and 21 fossil scorpions have been described from Burmese amber. This attests to a considerable degree of scorpion diversity in the Cretaceous Burmese amber-producing forests.

РЕЗЮМЕ. Изучение трех экземпляров скорпионов из мелового янтаря Мьянмы (Бирмы) привело к описаниям нового рода, Burmesescorpiops gen.n., с единственным (и типовым) видом B. groehni sp.n., и еще двух новых видов, Chaerilobuthus gigantosternum sp.n. and C. serratus sp.n., а также к подтверждению валидности подсемейства Archaeoscorpiopinae Lourenço, 2015. В настоящее время из бирманского янтаря известны 18 видов и 21 экземпляр ископаемых скорпионов. Это свидетельствует о значительном разнообразии скорпионов в меловых бирманских янтареносных лесах.

\section{Introduction}

After a recent completion of several papers [Lourenço, Beigel, 2011, 2015; Lourenço, 2015a, b, c, d; Lourenço, Velten, 2015], I had the opportunity to examine three new Burmese amber pieces containing scorpions. Their study leads to the description of one new genus and three new species, two belonging to a previously described genus. More importantly, however, are some new taxonomic characters shown by one of the specimens which allow for the validity of the recently described subfamily Archaeoscorpiopinae
Lourenço, 2015, to be clarified. This subfamily was based on a very incomplete specimen represented by a single pedipalp.

\section{Material and methods}

The specimens investigated are originally preserved in blocks of clear yellow and dark reddish amber. Details of each piece are provided together with the descriptions. Many characters, in particular trichobothria, are visible in some specimens, allowing for a detailed investigation to be carried out. The schematic drawings provided here are interpretations of what was observable. Illustrations and measurements were produced with the aid of a Wild M5 stereomicroscope equipped with a drawing tube and an ocular micrometer. Measurements follow Stahnke [1970] and are given in $\mathrm{mm}$. Trichobothrial notations follow Vachon [1974]. Trichobothria were definitely recorded only when their bothria (areoles) could be observed. Other trichobothria may be suggested by the presence of transverse hairs.

\section{Systematic part}

Family Palaeoeuscorpiidae Lourenço, 2003

Subfamily Archaeoscorpiopinae Lourenço, 2015

\section{Burmesescorpiops gen.n.}

DIAGNOSIS. Total length 10.62. General coloration yellow to bright yellow. Carapace with a moderately marked median concavity; median ocular tubercle anterior to centre of carapace; two lateral eyes can be observed. Pectines moderate in size, with 8-8 (8-9) teeth. Spiracles round to oval. Telson with a long pearshaped vesicle not flattened laterally; annular ring on telson not observed. General structure of pedipalps 
similar to that of Scorpiopinae, particularly Scorpiops Peters, 1861; fixed and movable fingers with 6-7 rows of small rounded granules, with inconspicuous accessory granules. The main differences are the reduced size of the apophysis on the internal aspect of the patella and a distinct trichobothrial pattern. This pattern is similar to type C of Vachon [1974], defined for the family Euscorpiidae [Vachon, 1980]. On the chela hand, trichobothria Db, Dt, Est, $\mathbf{E t}_{1-5} . \mathbf{E b}_{1}, \mathbf{E b}_{3}$ and 6-7 $\mathrm{V}$ can be observed. On the chela fixed finger, trichobothria eb, db, dsb, esb, dst, est and et can be observed. Patella showing $\mathbf{d}_{\mathbf{1}}$ and $\mathbf{d}_{\mathbf{2}}$ on dorsal face; $\mathbf{i}$ displaced to ventral face; $7 \mathbf{V}$ trichobothria are observed on the ventral face. Six/seven external trichobothria can be directly observed on the patella, but the presence of several transverse hairs suggests a higher number reaching a total of 13/14, which belong to et, est, esb and eb areas. Femur showing one d, i and e. A second, doubtful e seems to be present.

The generic name refers to the association of Burmese amber and the extant genus Scorpiops.

Type species: Burmesescorpiops groehni sp.n.

\section{Burmesescorpiops groehni sp.n.} Figs 1-11.

HOLOTYPE. Possibly a juvenile. Sex cannot be clearly determined, however, according to structure of the pectines it could be a female. Block of very clear yellow amber that measured 52 x $35 \times 11 \mathrm{~mm}$. Type locality and horizon: Myanmar (Burma), Kachin; precise locality unknown; Lower Cretaceous.

NAME. Honors Carsten Gröhn, Glinde, Germany, who arranged facilities for the study of the amber material.

REPOSITORY. The type specimen is deposited in the collection of the Geologisch-Paläontologisches Institut of the University of Hamburg (11038-2 GPIH 4564).

DESCRIPTION. Coloration: scorpion yellow to pale bright yellow; carapace and tergites yellow; metasomal segments I to IV yellow; segment V and telson slightly reddish yellow; pedipalps and legs yellow. Ventral aspect of holotype pale yellow.

Structure. Carapace with a few granulations, almost smooth; anterior margin with a moderately marked median concavity. Carinae absent; furrows weak. Median ocular tubercle anterior to centre of carapace (macula being displaced); median eyes moderate in size. Two lateral eyes can be observed on right side of carapace. Sternum pentagonal, larger than high. Mesosomal tergites weakly granular, with one median carina; VII with five weakly marked carinae. Pectines moderate in size, with 8-8 (8-9) teeth. Sternites smooth, with round to oval spiracles. Metasomal segments I to IV with 10-8-8-8 carinae; segment V slender, with seven carinae; dorsal carinae of segments I to IV with some minute spinoid granules; dorsal aspect of segments I to V weakly depressed; setation on all segments moderately marked. Telson with a long pear- shaped vesicle not flattened laterally; weakly granular to smooth; aculeus long and moderately curved; annular ring on telson not observed. Cheliceral dentition not visible. Pedipalp femur pentacarinate; patella with dorso-internal, ventro-internal, dorso-external and external carinae; internal face with some minor spinoid granules. Chela with moderately marked carinae; all faces weakly granular. Fixed and movable fingers each with 6-7 rows of small rounded granules; only inconspicuous accessory granules are observable; extremity of fingers with moderate spinoid granules; setation of pedipalps inconspicuous. Trichobothriotaxy recalling type C [Vachon, 1974] of extant Scorpiopinae (see diagnosis of the new genus).

Morphometric values (in $\mathrm{mm}$ ) of the holotype of Burmesescorpiops groehni sp.n. Total length 10.62 (including telson). Carapace: length 1.60, anterior width 0.87 , posterior width 1.54. Mesosoma length 3.34. Metasomal segments. I: length 0.54 , width 0.74 ; II: length 0.60 , width 0.54 ; III: length 0.74 , depth 0.40 ; IV: length 0.80 , depth 0.47 ; V: length 1.40 , depth 0.54 . Telson length 1.60. Vesicle: depth 0.47. Pedipalp: femur length 1.20 , width 0.54 ; patella length 1.54 , width 0.60 ; chela length 2.47 , width 0.74 , depth 0.33 . Sternum width 0.74 , depth 0.67 .

Family Chaerilobuthidae Lourenço et Beigel, 2011 Genus Chaerilobuthus Lourenço et Beigel, 2011

\section{Chaerilobuthus gigantosternum sp.n.} Figs 12, 13, 15, 16.

HOLOTYPE is a juvenile specimen, slighly larger than C. complexus Lourenço et Beigel, 2011, the first species described in this genus [Lourenço, Beigel, 2011], $5.83 \mathrm{~mm}$ in total length. Sex cannot be determined, but the structure of the body and appendages may suggest a female. The block of amber is very dark red and measured $29 \times 28 \times 6 \mathrm{~mm}$. The specimen is on the surface of the block, but only the ventral side can be observed. Some structures were damaged during the polishing process; besides this, many characters are not observable because the specimen suffered an important destruction process within the resin. The structure of the prosoma carapace, with absence of eyes, and the structure of a pecten clearly associate this scorpion with the genus Chaerilobuthus. The remarkable size of the sternum can distinguish this species from others in the genus.

Type locality and horizon: Myanmar (Burma), Kachin; precise locality unknown; Lower Cretaceous.

REPOSITORY. The type specimen is deposited in the collection of the Geologisch-Paläontologisches Institut of the University of Hamburg (11037-1 GPIH 4566).

The specific name refers to the remarkable size of the sternum.

DIAGNOSIS. The general structure shows similarities to that of the other species of Chaerilobuthus. Carapace smooth with a possible absence of eyes; very 

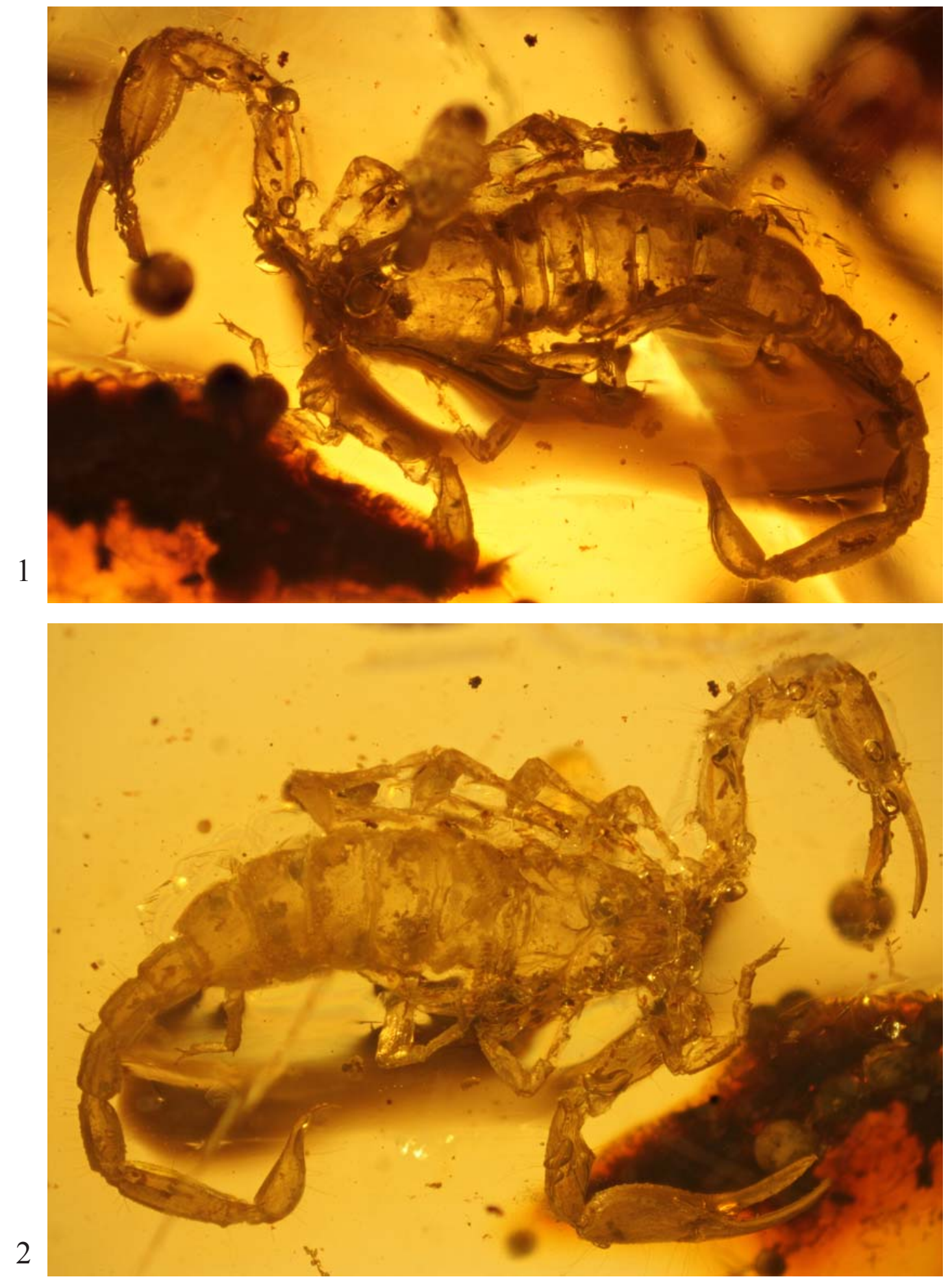

Figs 1-2. Burmesescorpiops groehni sp.n., habitus, dorsal and ventral aspects, respectively.

Рис. 1-2. Burmesescorpiops groehni sp.n., общий вид, соответственно сверху и снизу.

few trichobothria observed which can relate it to the pattern previously observed in Chaerilobuthus; two ventral trichobothria on chela. Pecten very small and bulky, with 5 teeth. Fixed and movable fingers each with one series of small rounded granules; very incon- spicuous accessory granules can be observed. Telson with a more or less bulbous vesicle: aculeus long and moderately curved; base of aculeus not enlarged. Tibial spurs not observable; probably very strongly reduced. 

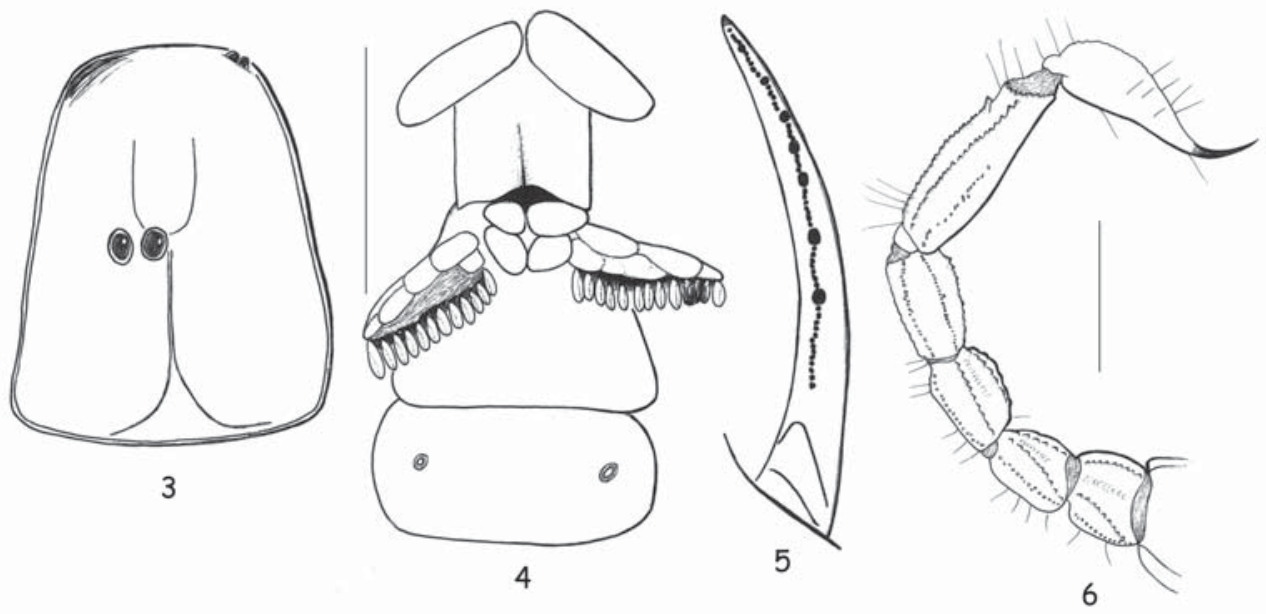

Figs 3-6. Burmesescorpiops groehni sp.n.: 3 - carapace; 4 - ventral aspect showing sternum, genital operculum, pectines, sternites and spiracles; 5 - cutting edge of movable finger with rows of granules; 6 - metasoma and telson, dorsolateral aspect. Scale bars: 1.0 $\mathrm{mm}$.

Рис. 3-6. Burmesescorpiops groehni sp.n.: 3 - карапакс; 4 - вид снизу, показывающий стернум, крышечку гениталий, пектины, стерниты и дыхальца; 5 - режущий край подвижного пальца с рядами гранул; 6 - метасома и тельсон, одновременно сверху и сбоку. Масштаб: 1,0 мм.

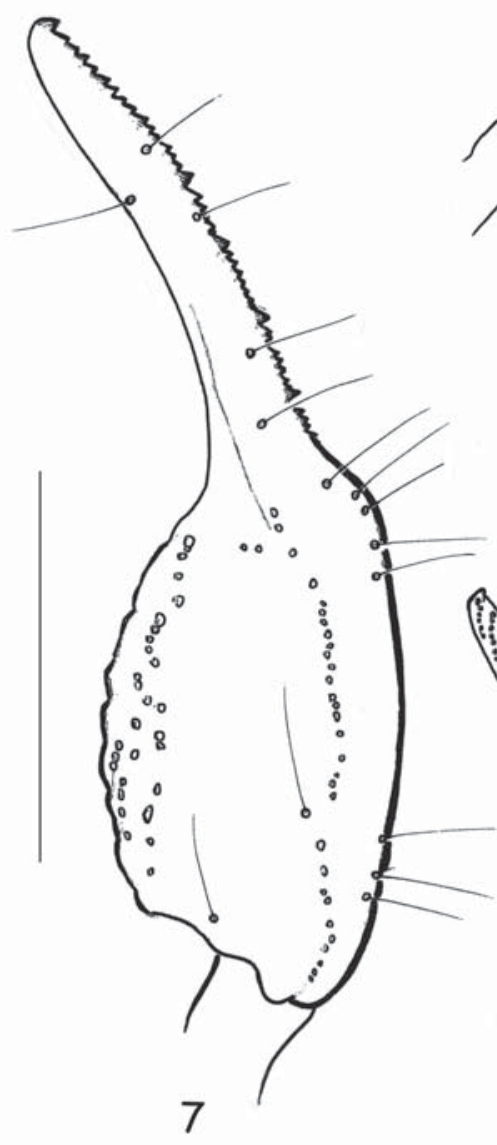

8
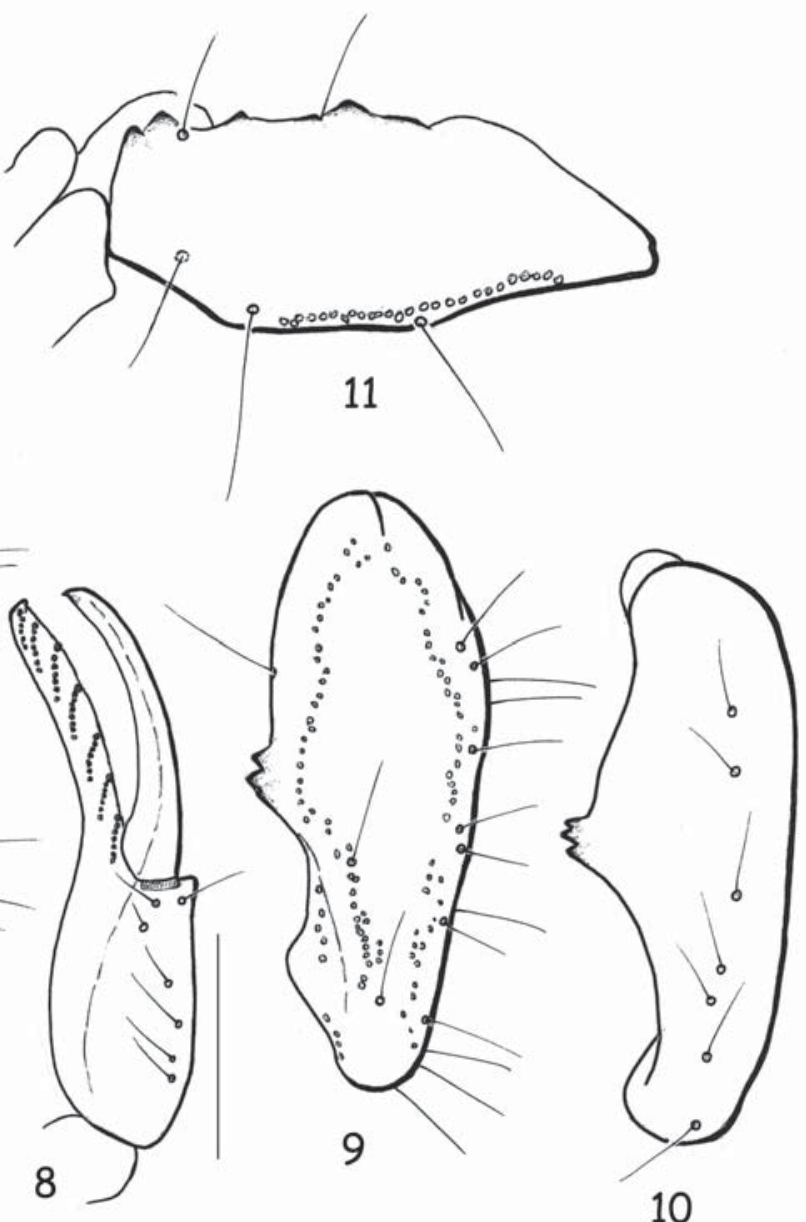

10

Figs 7-11. Burmesescorpiops groehni sp.n., trichobothrial pattern: 7-8 - chela, dorso-external and ventral aspects, respectively; 910 - patella, dorsal and ventral aspects, respectively; 11 - femur, dorsal aspect. Scale bars: $1.0 \mathrm{~mm}$.

Рис. 7-11. Burmesescorpiops groehni sp.n., характер трихоботриотаксии: 7-8 - ладонь, соответственно одновременно сверху и снаружи и снизу; 9-10 - коленная чашечка, соответственно сверху и снизу; 11 - бедро, сверху. Масштаб: 1,0 мм. 

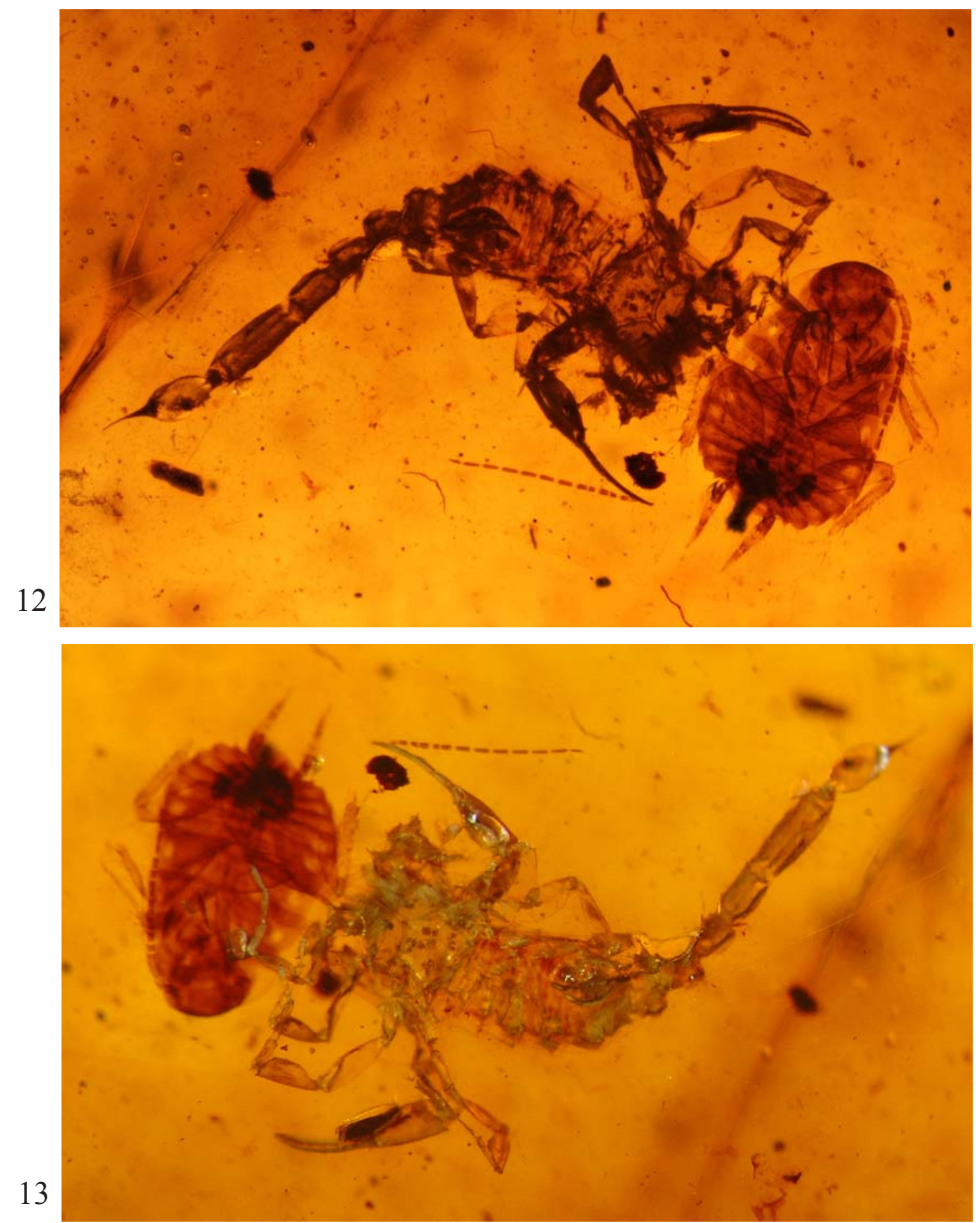

Figs 12-13. Chaerilobuthus gigantosternum sp.n., habitus, dorsal and ventral aspects, respectively.

Рис. 12-13. Chaerilobuthus gigantosternum sp.n., общий вид, соответственно сверху и снизу.

DESCRIPTION. Coloration: scorpion yellow to pale yellow. The specimen could be an exuvium. The dorsal aspect of the specimen cannot be clearly observed since the piece is thick and the amber is not clear enough.

Structure. Carapace seems smooth; anterior margin almost straight. Carinae and furrows not observable. Eyes indistinct, probably absent; median eyes, if present, are so small that they cannot be distinguished from bubbles in amber that hamper observation. Lateral eyes not observable. Sternum pentagonal and remarkably large; width and high are very similar. Mesosomal tergites not observable. Ventral aspect partially observable; one small, but very bulky pecten with 5 teeth; sternites with round spiracles. Metasomal segments I to IV with eight or ten carinae; the precise number cannot be clearly counted; segment V with 


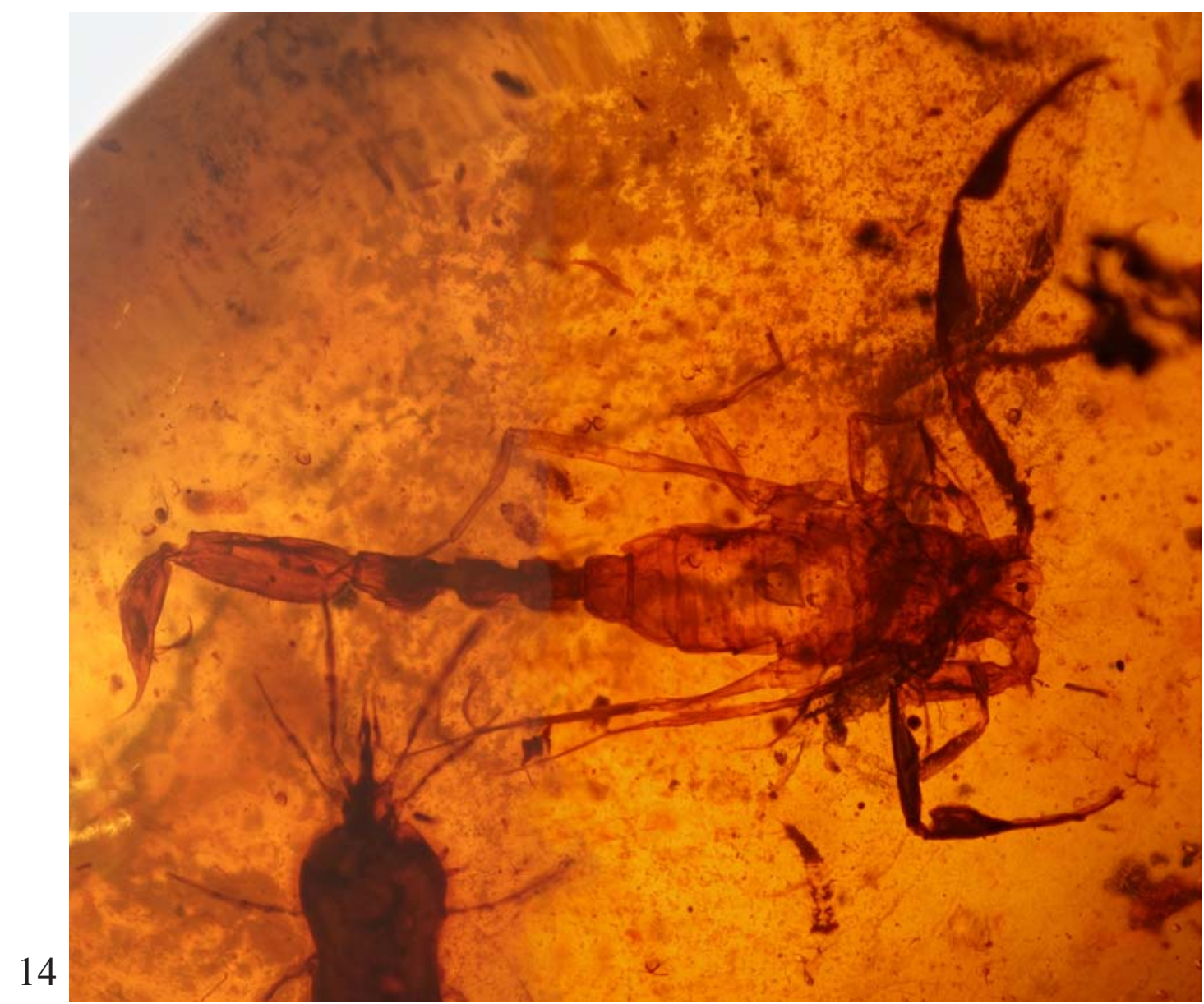

Fig. 14. Chaerilobuthus serratus sp.n., habitus, dorsal aspect. Рис. 14. Chaerilobuthus serratus sp.n., общий вид, сверху.

seven carinae; all carinae moderately marked; setation on segments I to $\mathrm{V}$ weakly developed. Telson with a more or less bulbous vesicle, not flattened dorsoventrally; weakly granular to smooth; aculeus long and moderately curved. Cheliceral dentition not visible. Pedipalp femur probably pentacarinate; no spinoid granules on internal face; patella with 5-6 carinae; internal face with only inconspicuous granules. Chela with moderately marked carinae; all faces almost smooth. Fixed and movable fingers with a longitudinal row of small, rounded granules, with inconspicuous accessory granules; extremity of fingers with one stronger spinoid granule. Trichobothriotaxy: trichobothrial pattern only very partially observed [Vachon, 1974]. Leg: tibial spurs maybe present, but extremely reduced.

Morphometric values (in $\mathrm{mm}$ ) of the juvenile holotype of Chaerilobuthus gigantosternum sp.n. Total length 5.83 (including telson). Carapace: length 1.00 , anterior width - , posterior width - . Mesosoma length 1.47. Metasomal segments. I: length 0.34 , width -; II: length 0.34 , width -; III: length 0.40 , width 0.27 ; IV: length 0.54 , width 0.27 ; V: length 0.80 , width 0.34 Telson length 0.94. Vesicle: width 0.14. Pedipalp: femur length 0.60 , width 0.14 ; patella length 0.74 , width
0.27 ; chela length 1.34 , width 0.34 , depth - . Sternum width 0.53 , depth 0.53 .

\section{Chaerilobuthus serratus sp.n.}

Figs 14, 17-19.

HOLOTYPE is a juvenile specimen, almost twice the size of the previous species, $10.30 \mathrm{~mm}$ in total length. Sex cannot be determined, but the structure of the body and appendages may suggest a male. The specimen is included in the same block of amber containing the previous species. Again, most characters are not observable because the specimen suffered from the destruction process within the resin, the amber is not clear and the piece is too thick over the dorsal aspect of the scorpion. The general structure of the scorpion clearly associates it to the genus Chaerilobuthus.

Type locality and horizon: Myanmar (Burma), Kachin; precise locality unknown; Lower Cretaceous.

The specific name refers to the serrulas present on the dorsal carinae of metasomal segments.

REPOSITORY. The type specimen is deposited in the collection of the Geologisch-Paläontologisches In- 


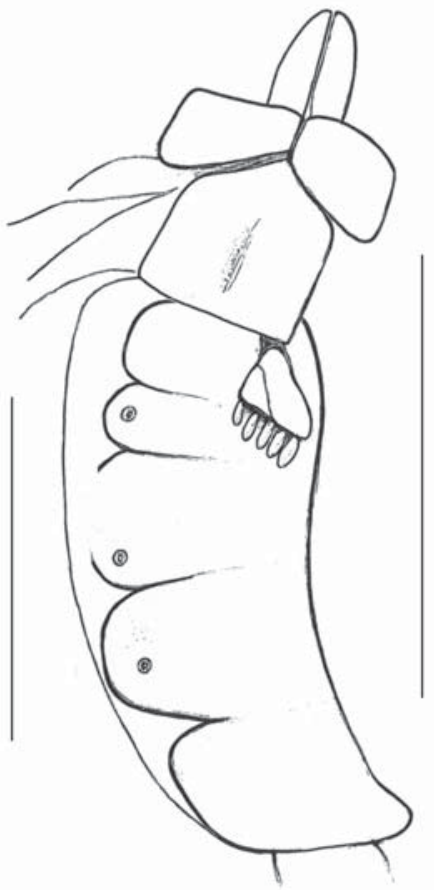

15

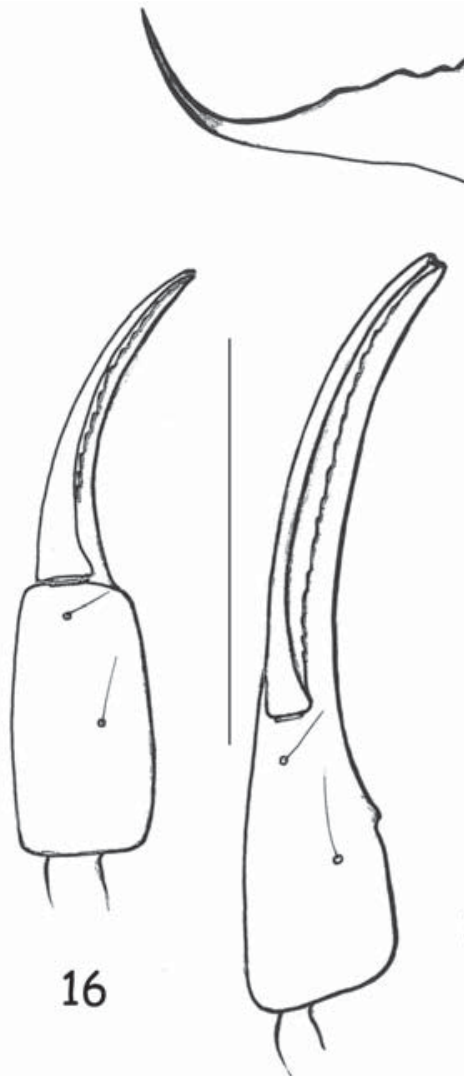

17

Figs 15-19. Chaerilobuthus gigantosternum sp.n. (15-16) and Chaerilobuthus serratus sp.n. (17-19): 15 — ventral aspect showing coxapophysis, sternum, pecten and sternites with spiracles; 16-17 - chela, ventral aspect showing trichobothria; 18 - metasomal segments IV-V and telson, lateral aspect showing serrulas; 19 - sternites V-VII with spiracles and metasomal segments I-IV. Scale bars: $1.0 \mathrm{~mm}$.

Рис. 15-19. Chaerilobuthus gigantosternum sp.n. (15-16) и Chaerilobuthus serratus sp.n. (17-19): 15 - вид снизу, показывающий отросток тазика, стернум, гребешок и стерниты с дыхальцами; 16-17 - ладонь, снизу для того, чтобы показать трихоботрии; 18 - сегменты IV-V метасомы и тельсон, сбоку, чтобы показать серрулы; 19 - стерниты V-VII с дыхальцами и сегментами I-IV метасомы. Масштаб: 1,0 мм.

stitut of the University of Hamburg (11037-2 GPIH 4567).

DIAGNOSIS. The specimen can be associated to the genus Chaerilobuthus by its general structure. The following combination of features can be used to diagnose the new species: Carapace apparently with inconspicuous eyes; two ventral trichobothria on chela-hand. Fixed and movable fingers of pedipalp chela each with a series of small rounded granules separated by inconspicuous accessory granules. Dorsal carinae of metasomal segments IV and V with conspicuous serrulas. Telson with a non-bulbous vesicle: aculeus moderately long and curved; base of aculeus not enlarged. Tibial spurs absent from legs III and IV.

DESCRIPTION. Coloration: scorpion reddish to reddish-brown; the process of destruction suffered by the specimen seems less intense than that of the previous species. The dorsal aspect of the specimen cannot be clearly observed.

Structure. Carapace apparently smooth; anterior margin possibly straight. Carinae and furrows not ob- servable. Median eyes inconspicuous. Lateral eyes not observable. Sternum pentagonal. Mesosomal tergites not observable. Ventral aspect with smooth sternites and round spiracles; pectines apparently destroyed. Metasomal segments I to IV with 6-8-8-8 carinae; ventral carinae absent from segment I; segment $\mathrm{V}$ with seven carinae; all carinae moderately marked; dorsal carinae of segments IV and V with a series of spinoid granules forming serrulas; setation on segments I to $\mathrm{V}$ moderately developed. Telson with a non-bulbous vesicle, not flattened dorsoventrally; weakly granular to smooth; aculeus moderately long and curved. Cheliceral dentition not observable. Pedipalps long and slender; femur probably pentacarinate; patella with 5-6 carinae. Chela with moderately marked carinae; all faces almost smooth. Fixed and movable fingers with a series of small, rounded granules, separated by moderately marked accessory granules; extremity of fingers with a stronger spinoid granule. Trichobothriotaxy: trichobothrial pattern only very partially observed [Vachon, 1974]. Leg: tibial spurs absent. 
Morphometric values (in $\mathrm{mm}$ ) of the juvenile holotype of Chaerilobuthus serratus sp.n. Total length 10.30 (including telson). Carapace: length 1.54, anterior width - , posterior width - Mesosoma length 2.80. Metasomal segments. I: length 0.47 , width 0.60 ; II: length 0.54 , width 0.54 ; III: length 0.67 , depth 0.47 ; IV: length 0.94 , depth $0.54 ; \mathrm{V}$ : length 1.60 , depth 0.67 . Telson length 1.74. Vesicle: depth 0.40. Pedipalp: femur length 1.27 , width 0.34 ; patella length 1.34 , width 0.34 ; chela length 1.87 , width 0.40 , depth - .

ACKNOWLEDGEMENTS. I am most grateful to Carsten Gröhn, Glinde, Germany for arranging facilities for the study of the specimens, to Elise-Anne Leguin (MNHN, Paris) for the assistance with the preparation of plates and to Sergei Golovatch, Russian Academy of Sciences, Moscow for his interest in the publication of this article and for the translation of the title and abstract in Russian.

\section{References}

Lourenço W.R. 2015a. A new subfamily, genus and species of fossil scorpions from Cretaceous Burmese amber (Scorpiones: Palaeoeuscorpiidae) // Beiträge zur Araneologie. Vol. 9. P.457464.

Lourenço W.R. 2015b. Clarification of the familial status of the genus Palaeoburmesebuthus Lourenço, 2002 from Cretaceous Burmese amber (Scorpiones: Archaeobuthidae: Palaeoburmesebuthinae) // Beiträge zur Araneologie. Vol.9. P.465-475.
Lourenço W.R. 2015c. A new contribution to the knowledge of Cretaceous Burmese amber scorpions with the description of two new species of Betaburmesebuthus Lourenço, 2015 (Scorpiones: Archaeobuthidae: Palaeoburmesebuthinae) // Arachnida - Rivista Aracnologica Italiana. Vol.3. P.27-36.

Lourenço W.R. 2015d. An unusual new species of Chaerilobuthus Lourenço \& Beigel, 2011 (Scorpiones: Chaerilobuthidae) from the Cretaceous amber of Myanmar (Burma) // Arachnida Rivista Aracnologica Italiana. Vol.5. P.44-48.

Lourenço W.R., Beigel A. 2011. A new scorpion fossil from the Cretaceous amber of Myanmar (Burma). New phylogenetic implications // Comptes Rendus Palevol. Vol.10. P.635-639.

Lourenço W.R., Beigel A. 2015. A new genus and species of Palaeoburmesebuthinae Lourenço, 2015 (Scorpiones: Archaeobuthidae:) from Cretaceous amber of Myanmar // Beiträge zur Araneologie. Vol.9. P.476-480.

Lourenço W.R., Velten J. 2015. Another new species of Chaerilobuthus Lourenço \& Beigel, 2011 (Scorpiones: Chaerilobuthidae) from the Cretaceous amber of Myanmar (Burma) // Arachnida - Rivista Aracnologica Italiana. Vol.5. P.2-8.

Stahnke H.L. 1970. Scorpion nomenclature and mensuration // Entomological News. Vol.81. P.297-316.

Vachon M. 1974. Etude des caractères utilisés pour classer les familles et les genres de Scorpions (Arachnides). 1. La trichobothriotaxie en arachnologie. Sigles trichobothriaux et types de trichobothriotaxie chez les Scorpions // Bulletin du Muséum national d'Histoire naturelle, Paris. 3è sér. T.140. P.857-958.

Vachon M. 1980. Essai d'une classification sous-générique des Scorpions du genre Scorpiops Peters, 1861 (Arachnida, Scorpionida, Vaejovidae) // Bulletin du Muséum national d'Histoire naturelle, Paris. 4e sér. T.2. P.143-160.

Responsible editor S.I. Golovatch 